\title{
Kesalahpahaman Makna Gugatan Perwakilan Kelompok dan Legal Standing di Indonesia
}

\author{
Machsun Tabroni
}

\begin{abstract}
Alongside conventional civil suits, the development of the civil law of procedure has led to the emergence of class action and legal standing. A class action is filed by one or more -persons in their own interests, but also on behalf of and in the interests of a large group of people; whereas legal standing is merely an "entrance ticket" to the legal battle which has many obstacles. Among others, these obstacles include evidence of proof the remedial tools available, and even the obstacle of the readiness of the council of judges to make the best decision.
\end{abstract}

\section{Pendahuluan}

Perkembangan ekonomi dewasa ini makin mengarah kepada produksi barang atau jasa yang bersifat massal. Produksi yang bersifat massal itu memiliki potensi kerugian yang bersifat massal pula. ${ }^{1}$ Kerugian tersebut dapat berupa pencemaran lingkungan hidup dari limbah industri, penebangan hutan yang mengakibatkan banjir sehingga merugikan masyarakat. Konsumen dapat pula menderita kerugian secara massal karena cacat produk.

Jika dilakukan gugatan secara konvensional muncul masalah yaitu apabila korban akibat kejadian tersebut di atas bersifat massal. Masingmasing korban harus mengajukan gugatan. Para korban dapat pula memberikan kuasa kepada pemegang kuasa atau pengacara untuk melakukan gugatan. Persoalan lain juga akan timbul, jika gugatan tersebut dikabulkan dan berkekuatan hukum tetap, siapakah yang berhak menerima ganti rugi? Apakah hanya diberikan kepada korban yang secara formal ikut menggugat saja? Bagaimana pula nasib para korban yang tidak ikut mengajukan gugatan, apakah mereka juga berhak atas ganti rugi tersebut? Apakah mereka harus mengajukan gugatan baru? Bagaimana jika gugatan penggugat dikalahkan? Siapa yang harus menanggung biaya perkara? Mekanisme semacam ini sangat tidak praktis dan menghabiskan waktu, biaya, dan tenaga. ${ }^{2}$

Dalam perkembangan hukum acara perdata, di samping gugatan perdata

1 Susanti Adi Nugroho, Praktek Gugatan Perwakilan Kelompok (Class Action) (Jakarta: Mahkamah Agung'Rl, 2002), hlm.1

${ }^{2}$ Ibid., him.3 
konvensional itu, lahir pula gugatan perwakilan kelompok (class action). Gugatan perwakilan kelompok mengacu kepada suatu gugatan perwakilan oleh seseorang untuk kepentingan dirinya sendiri dan kepentingan kelompok dalam jumlah yang besar (plaintiff class action). Gugatan ini juga mengacu kepada suatu pengajuan gugatan secara perwakilan terhadap seseorang atau lebih yang ditunjuk untuk membeia kepentingan diri sendiri dan kelompok dalam jumlah yang besar (defendant class action). ${ }^{3}$

Gugatan perwakilan kelompok merupakan prosedur beracara dalam suatu perkara perdata yang memberikan hak beracara terhadap satu orang atau lebih bertindak sebagai penggugat untuk memperjuangkan kepentingan para penggugat- sendiri sekaligus mewakili kepentingan orang banyak yang mengalami kesamaan penderitaan atau kepentingan. Penggunaan gugatan perwakilan memiliki legitimasi sebagai gugatan yang melibatkan orang banyak yang mengalami penderitaan atau kerugian. Dengan adanya gugatan perwakilan ini, maka persoalan ketidakpraktisan dan ketidakefisienan gugatan konvensional dapat. diatasi. ${ }^{4}$

\section{Awal Mula Gugatan Perwakilan Kēlompok}

Sesungguhnya, gugatan perwakilan kelompok ini sudah dikenal di Inggris sejak abad delapan belas. Sebelum 1873, gugatan penwakilan kelompok hanya berlaku di Court of Chancery. Setelah 1873, gugatan perwakilan telah pula diatur dalam Supreme Court of Judicature Act. ${ }^{5}$ Di negara-negara civil law, dikenal pula prosedur pengajuan gugatan yang melibatkan kepentingan umum secara perwakilan, yakni actio popularis. Menurut Kottenhagen-Edgez, dalam actio popularis setiap orang dapat menggugat atas nama kepentingan umum dengan menggunakan Pasal 1401 Burgerlijk Wetboek Belanda (Baru). ${ }^{6}$ Gugatan semacam itu sebangun dengan citizen lawsuit dalam sistem common law. Gugatan semacam ini dapat diterapkan terhadap pelanggaran perlindungan lingkungan oleh warga negara yang menderita kerugian baik secara langsung maupun tidak. ${ }^{\text {? Oleh karena }}$ masalah perlindungan lingkungan merupakan kepentingan umum atau kepentingan masyarakat luas, sehingga setiap warga negara berhak menuntutnya. Selain actio popularis, di Belanda dikenal pula groep acties. Groep acties ini mewakili kepentingan orang banyak. Prosedur groep acties ini memiliki makna sebagai hak yang diberikan oleh hukum kepada suatu badan hukum untuk mengajukan gugatan yang mewakili kepentingan orang banyak. Prosedur ini memberikan hak gugat

\footnotetext{
${ }^{3}$ lbid, hlm 20

‘ Mas Achmad Santoso, et. al., Pedoman Penggunaan Gugatan Perwakilan (Jakarta: ICEL - PIAC YLBHI, 1999), hlm.1

5 lbid, hlm 25.

${ }^{6}$ Paulus Efendi Lotulung, Penegakan Hukum Lingkungan oleh Hakim Perdata (Bandung: Citra Aditya Bakti, 1993), hlm 57.

${ }^{7}$ Mas Achmad Santosa, Konsep dan Penerapan Gugatan Perwakilan (Class Action) (Jakarta: ICEL, 1997), hlm 20.
} 
kepada hukum untuk mewakili kepentingan orang banyak atau kepentingan umum. ${ }^{8}$

Di Amerika Serikat, gugatan perwakilan kelompok diatur dalam US Federal Rule of Civil Procedure pada 1938. Pada 1966 melalui Pasal $23^{\prime}$ US Federal Rule of Civil Procedure, ${ }^{9}$ hukum àcara gugatan perwakilan kelompok telah disempurnakan. Pasal 23 US Federal Rule of Civil Procedure, menentukan bahwa gugatan ini mengacu kepada gugatan perdata (yang biasanya berkaitan dengan permintaan injuction atau ganti rugi) yang diajukan oleh sejumlah orang (dalam jumlah yang tidak banyak) yang mewakili kepentingan ratusan atau ribuan orang lain yang juga menjadi korban. Gugatan perwakilan kelompok pertamakali terjadi di Amerika Serikat yang dilakukan oleh para pemegang saham perusahaan asosiasi yang bukan badan hukum. Gugatan itu menuntut direktur atas kepemilikan saham melalui transaksi yang sudah sesuaj dengan ketentuan hukum. Para penggugat yang mewakili para anggotanya gagal melakukan tindakan hukum dengan alasan para penggugat tidak secara wajar melindungi kepentingan para pemegang saham atau para anggota yang memiliki hak yang sama dari perusahaan atau asosiasi tersebut. Gugatan tersebut dapat diterima atau ditolak berdasarkan keputusan hakim.

\section{Eksistensi Hukum Gugatan Perwakilan Kelompok di Indonesia}

Lembaga gugatan perwakilan kelompok yang berasal dari sistem common lawini belum begitu lama dikenal di Indonesia. UndangUndang Nomor 23 Tahun 1997 tentang Pengelolaan Lingkungan Hidup' (UUPLH) mengintroduksikan mekanisme pengajuan' gugatan oleh sekolompók kecil masyarakat untuk bertindak mewakili masyarakat dalam jumlah banyak yang dirugikan atas dasar kesamaan permasalahan, fakta hukum, dan tuntutan yang ditimbuilkan oleh pencemaran dan atau perúsakan lingkungan hidûp. Pasal 37 ayat (1) UUPLH menyatakan bahwa masyarakat berhak mengajukan gugatan perwakilan kelompok ke pengadilan dan atau. melaporkan ke penegak. hukum mengenai berbagai masalah lingkungan hidup yang merugikan peri kehidupan másyarakat. Ayat (2) pasal yang sama menyebutkan, jika diketahui bahwa masyarakat menderita karena akibat pencemaran dan atau perusakan lingkungan hidup sedemikian rupa sehingga mempengarühi kehidupan masyarakat, maka instansi pemerintah yang bertanggung jawab di bidang lingkungan hidup dapat bertindak untuk kepentingan masyarakat. Berkaitan dengan gugatan perwakilan kelompok diatur dalam Pasal 37 ayat (1) UUPLH. Pasal yang menyatakan bahwa ada tiga hal yang harus ada dalam suatu gugatan perwakilan kelompok, yakni:

1. hak kelompok kecil masyarakat untuk bertindak mewakili mereka sendiri dan sekelompok masyarakat dalam jumlah besar yang dirugikan;

2. pihak yang diwakili dalam jumlah besar; dan

3. atas dasar adanyakesamaan permasalahan,

${ }^{8} \mathrm{lbid}$, hlm 53.

${ }^{9} \mathrm{lbid}, \mathrm{hlm} .25$ 
baik persamaan fakta, persamaan hukum, dan tuntutan.

Undang-Undang Nomor 8 Tahun 1999 tentang.Perlindungan Konsumen (UUPK) juga mengintroduksikan pengajuan sengketa konsumen oleh sekelompok konsumen yang memiliki kesamaan kepentingan secara gugatan perwakilan kelompok. Pasal 46 ayat (1) UUPK menyebutkan bahwa gugatan atas pelanggaran pelaku usaha dapat dilakukan oleh:

1. seorang konsumen yang dirugikan atau ahli waris yang bersangkutan;

2. sekelompok konsumen yang mempunyai kepentingan yang sama;

3. lembaga perlindungan konsumen swadaya masyarakat yang memenuhi syarat, yakni berbentuk badan hukum atau yayasan, yang dalam anggaran dasarnya menyebutkan -dengan tegas bahwa tujuan didirikannya organisasi tersebüt adalah untuk kepentingan perlindungan konsumen dan telah melaksanakan kegiatan sesuai dengan anggaran dasamya;

4. pemerintah dan atau instansi terkait apabila barang dan atau jasa yang dikonsumsi atau dimanfaatkan meñgakibatkan kerugian materiyang besar dân atau korban yangtidak sedikit.

- Pasal 71 ayat (1) Uñdang-Undang Nomor. 41 Tahun 1999 juga mengintroduksikan pengajuan gugatan oleh masyarakat dalam bidang kehutanan secara perwakilan. Pasal tersebut menyatakan bahwa, masyarakat berhak mengajukan gugatan perwakilan kelompok ke pengadilan dan atau melaporkan ke penegak hukum terhadap kerusakan hutan yang merugikan kehidupan masyarakat.
Pasal 1 huruf e Peraturan Mahkamah Agung Republik Indonesia (PERMA) Nomor 2 Tahun 1999 tentang Pengawasan Partai Politik oleh Mahkamah Agung, memberikan kesempatan adanya gugatan perwakilan masyarakat.

Lembaga gugatan perwakilan kelompok ini merupakan dimensi baru dalam hukum acara perdata Indonesia, namun baik dari segi konsep maupun implementasinya belum begitu jelas, dan masih menimbulkan sejumlah permasalahan.

Mengingat masih belum jelasnya konsep tersebut, seringkali praktisi hukum di Indonesia mencampuradukkan pengertian atau konsep gugatan perwakilan kelompok dengan konsep hak gugat (standing). Padahal keduanya memiliki perbedaan konsep yang mendasar. Hak gugat ini merupakan akses perorangan maupun kelompok atau organisasi yang bertindak untuk dan atas nama kepentingan publik maupun kepentingan lingkungan hidup ke pengadilan sebagai penggugat. Hak gugat organisasi lingkungan hidup merupakan salah satu bagian dari standing law...$^{10}$ Dengan demikian, sesungguhnya apa yang dilakukan oleh Yayasan Wahana Lingkungan selama dalam memberikan advokasi lingkungan, tidak termasuk dalam kategori gugatan perwakilan kelompok, tetapi sebagai pelaksanaan dari hak gugat yang diakui UUPLH. Pasal 38 ayat (1) UUPLH sendir menyatakan bahwa dalam rangka pelaksanaan tanggung jawab pengelolaan lingkungan sesuai dengan pola kemitraan, organisasi lingkungan hidup berhak mengajukan gugatan untuk kepentingan pelestarian fungsi lingkungan hidup.

Walaupun telah ada pengakuan

${ }^{10}$ Susanti Adi Nugroho, op cit, hlm.9 
keberadaan gugatan perwakilan kelompok dalam beberapa peraturan perundangundangan, namun sampai saat ini belum ada peraturan perundang-undangan yang mengatur hukum acaranya. Untuk mengisi kekosongan hukum acara tersebut, Mahkamah Agung telah mengeluarkan Peraturan Mahkamah Agung (PERMA) Republik Indonesia Nomor 1 Tahun 2002 tentang Gugatan Perwakilan Kelompok. Dari sisi hukum acara yang berlaku di Indonesia, gugatan perwakilan kelompok menimbulkan masalah yang berkaitan dengan legitima persona standi in judicio dari para pihak yang maju ke pengadilan.

Di dalam mekanisme gugatan perwakilan kelompok, setiap anggota kelompok memiliki kesempatan untuk menjadi pihak yang maju ke pengadilan mewakili kelompok tersebut. Dalam kenyataannya, tidak semua anggota kelompok mempunyai kemampuan yang sama dalam memahami apa yang menjadi kepentingan kelompok. Apa yang dituntut oleh wakil kelompok belum tentu merupakan kepentingan kelompok. Di sisi lain, hukum acara perdata Indonesia tentang pihak yang dapat mengajukan tuntutan hak ke pengadilan merupakan point $d^{\prime}$ interest point $d^{\prime}$ action. Menurut sistem hukum acara Indonesia, orang yang dapat menjadi pihak dalam sengketa perdata meliputi manusia dan badan hukum melalui wakilnya. Di sisi lain, prinsip gugatan. perwakilan kelompok dalam pengertian yang sebenarnya tidak memberikan legitima persona standi in judicio pada badan hukum atau korporasi untuk mewakili kepentingan kelompok.

Hukum acara perdata yang berlaku sekarang ini, memang belum mengatur gugatan perwakilan kelompok, padahal dalam praktik pengadilan, gugatan -perwakilan kelompok terus meningkat. Oleh karena itu, adanya aturan bagi pelaksanaan gugatan perwakilan kelompok semakin dibutuhkan. Untuk mengatasi hal tersebut, Mahkamah Agung telah mengeluarkan PERMA Nomer 1 Tahun 2002 tentang Gugatan Perwakilan Kelompok tetapi, ini hanya merupakan praktik jalan pintas untuk mengisi kekosongan hukum dalam memenuhi kebutuhan praktik peradilan."

Șistem hukum acara harus. lengkap. Sistem hukum acara yang baik harus menyediakan lembaga-lembaga yang memadai untuk kepentingan penuntutan hak ke pengadilan, baik yang menyangkut kepentingan penuntutan hak oleh seseorang atau lebih maupun sekelompok orang dalam jumlah yang besar atau masyarakat luas. Proses penegakan hukum melaiui pengadilan yang tidak memadai, akan mendorong pencari keadilan untuk menyelesaikannya di luar pengadilan. Ketiadaan atau kekuranglengkapan sàrana (perangkat hukumnya) yang dapat dipergunakan oleh sekelompok orang dalam jumlah yang besar atau masyarakat luas untuk menuntut haknya melalui lembaga pengadilan maupun lembaga di luar pengadilan, dapat menimbulkan kerawanan. Untuk menghindari kerawanan itu diperlukan perangkat hukum acara yang memadai bagi masyarakat untuk dapat menuntut haknya. ${ }^{2}$

"Paulus Effendie Lotulung, "Keynotè Speech", Lokakarya Acara Gugatan Perwakilan Kelompok (Class Action), (Forum Kajian Hukum Fakultas Hukum Universitas Pakuan - Lembaga Penelitian dan Pertimbangan Hukum Administrasi Negara, Bogor, 27 Juli 2002), hlm 1-5

${ }^{12}$ E. Sundari, op cit, hlm 3 
Keberadaan PERMA Nomor 1 Tahun 2002 tentang Gugatan Perwakilan Kelompok dari segi yuridisnya sendiri masih menimbulkan permasalahan. Bentuk. peraturan perundang-undangan seperti ini tidak dikenal dalam tata urutan peraturan perundang-undangan Indonesia. Kekuatan hukumnya masih dipertanyakan. Apabila terjadi pertentangan antara PERMA dan HIR atau RBG, mana yang harus didahulukan? Secara yuridis formal, PERMA itu bukan lex specialis dari HIR atau RBG, karena ia tidak sederajat. Di lain pihak PERMA ini sendiri menjadikan HIR atau RBG sebagai dasarnya. Substansi PERMA tersebut, pada dasarnya hanya berisi prosedur saja, banyak hal yang belum diatur baik oleh PERMA maupun peraturan perundangundangan lainnya, misainya bagaimana cara penentuan ganti rugi. Jika gugatan tersebut diterima dan berkuatan hukum yang tetap, bagaimana cara mendištribusikan ganti rugi tersebut. Bagaimana jika ada yang menerima dan menolak putusan pengadilan.

Konsep gugatan perwakilan merupakan salah satu kekhususan prosedur pengajuan gugatan yang melibatkan orang banyak sebagai pihak dengan satu atau lebih tuntutan. ${ }^{13}$ Tuntutan tersebut dapat meliputi tuntutan ganti rugi, tuntutan pernyataan bahwa suatu kelompok berhak atas ganti kerugian dan tuntutan perintah bagi tergugat untuk melakukan perbuatan tertentu atau tidak melakukan perbuatan tertentu.

Pengertian gugatan perwakilan kelompok menurut Thomas J. Harron adalah, "a court case brought by number of person on behalf of themselves and all other person similarly aggrieved". ${ }^{14}$ Michael B. Metzger mengartikan gugatan perwakilan kelompok sebagai "an action brought on behalf of the plaintiff and other similarly situated". ${ }^{15}$ Black's Law Dictionary mengartikan class or representative action sebagai "...a means by which, where a large group of person are interested in a matter, one or more may sue or be sued as representatives of the class without needing to joint every member of the class". 16 Kupchale dan Hyland menjelaskan gugatan perwakilan kelompok sebagai tuntutan yang dapat diajukan atas nama seluruh anggota suatu kelompok tertentu meskipun mereka tidak diketahui satu persatu secara individual, tetapi sudah diketahui suatu kelompok atau masyarakat tertentu. ${ }^{17}$

Dari pengertian di atas dapat ditarik kesimpulan bahwa gugatan perwakilan kelompok (class action) memiliki unsur-unsur sebagai berikut:

1. suatu gugatan perdata;

2. diajukan oleh satu atau sekelompok orang atau suatu lembaga tertentu, dalam hal ini biasanya oleh Lembaga Swadaya Masyarakat (LSM);

3. sebagai wakil dari masyarakat yang dirugikan;

4. ditujukan terhadap orang perorangan,

${ }^{13}$ Mary Kay Kane, Civil Procedure, Third Edition (Minnesota: West Publishing Co., St. Paul, , 1991), hlm 251.

${ }^{14}$ Thomas J. Harron, Business Law (Boston: Allyn and Bacon, 1981), hlm 3.

${ }^{15}$ Michael B. Metzger, et al, Business Law and The Regulatory of Environment (Illinois: Irwin, 1986), hlm 207.

${ }^{16}$ Henry Campbell Black, Black's Law Dictionary (St. Paul, Minn: West Publishing Co., 1979), hlm 226.

${ }^{17}$ Kupchale, Charles E. \& Margareth C. Hyland, Environmental Science (Massachusetts: Allyn \& Bacon, 1986) hlm 549. 
lembaga atau kelompok lembaga yang mempunyai tanggung jawab terhadap masyarakat;

5. class representatives maupun class members ${ }^{18}$ harus mempunyai kesamaan fakta, kepentingan, permasalahan dan tuntutan hukum;

6. class representatives maupun class members merupakan pihak yang menjadi korban dari pihak lain.

Menurut Order 15, Rule 12 English Rules of Supreme Court, 1965, ada dua syarat untuk mengajukan gugatan perwakilan kelompok yaitu adanya sejumlah besar orang (numerous person) dan adanya kepentingan atau permasalahan yang sama (common issue or interest). Selain kedua syarat tersebut, di Amerika Serikat berdasarkan Rule 23 a Federal Rules of Civil Procedure, 1966, masih ada dua syarat lain, yakni adanya tuntutan yang sama dari seluruh anggota (typical claims) dan adanya wakil kelompok yang dianggap jujur dan benar-benar melindungi kepentingan kelompok (fair and adequate).

\section{Kesalahpahaman Makna Gugatan Perwakilan Kelompok dan Legal Standing}

Sistem beracara dengan menggunakan prosedur class action pada awalnya hanya dikenal di negara-negara Anglo Saxon. Di negara-negara Eropa Kontinental dikenal bentuk lain dari prosedur pengajuan gugatan yang melibatkan kepentingan sejumlah besar orang secara perwakilan. Di dalam hukum Romawi, prosedur pengajuan gugatan yang melibatkan kepentingan umum secara perwakilan, disebut actio popularis. ${ }^{19}$ Actio popularis merupakan gugatan yang dapat diajukan oleh setiap warga negara, atas nama kepentingan umum berdasarkan perbuatan melawan hukum. Dapat disimpulkan bahwa pengertian actio popularis adalah pengajuan gugatan yang dapat dilakukan oleh setiap orang terhadap adanya perbuatan melawan hukum; dengan. mengatasnamakan *kepentingan umum, berdasarkan peraturan perundang-undangan yang mengatur adanya prosedur tersebut.

Pengertian kepentingan umum (public interest) adalah something in which the public, the community at large, has some pecuniary interest, or some interest by which their legal rights or liabilities are affected..$^{20} \mathrm{Ada}$ berbagai batasan kepentingan umum dalam peraturan perundang-undangan di Indonesia. Soedikno Mertokusumo menyimpulkan bahwa yang dimaksud dengan kepentingan umum adalah kepentingan yang harus didahulukan daripada kepentingan lainnya, yang menyangkut kepentingan bangsa dan negara, pelayanan umum dalam masyarakat luas, rakyat banyak dan atau pembangunan di berbagai bidang kehidupan, dengan tetap memperhatikan

${ }^{18}$ Class members adalah masyarakat yang dirugikan oleh pihak lain, sedangkan class representatives adalah individu atau kelompok atau lembaga (LSM) yang mewakili class members.

${ }^{19}$ E. Sundari, op.cit, hlm 15.

${ }^{20}$ Henry Campbell Black, Black's Law Dictionary, Sixth Edition, (ST. Paul, Minn: West Publishing Co. 1990), hlm 1229. $45-46$.

${ }^{21}$ Sudikno Mertokusumo, Hukum Acara Perdata Indonesia, ed. Kelima, (Yogyakarta: Liberty. 1996), hlm 
proporsi pentingnya dan tetap menghormati kepentingan yang lain, dimana dalam menetapkan dan memelihara kepentingan pribadi tidak boleh merugikan kepentingan umum atau masyarakat. 21 -

Berdasarkan pengertian kepentingan umum apabila dikaitkan dengan kepentingan yang hendak dituntut dengan prosedur actio popularis dapat meliputi pelayanan umum dalam masyarakat luas. Pelayanan umum itu antara pelayanan kesehatan, keamanan, dan kedamaian masyarakat oleh pemerintah yang selama ini dianggap oleh masyarakat belum memadai, pengadaan angkutan -umum, pengadaan air minum, listrik, perlindungan lingkungan, perlindungan hutan dan lain-lain. Oleh karena masalah tersebut merupakan kepentingan masyarakat luas, maka setiap orang yang pada hakekatnya adalah anggota masyarakat sangat berkepentingan untuk menuntutnya. Gugatan sëcara actio popularis juga dapat diajukan terhadap pihak swasta, yang ikut menyelenggarakan pelayanan umum.

Prinsip actio popularis memiliki persamaan dengan prinsip gugatan perwakilan kelompok. Keduanya sama-sama berkaitan dengan pengajuan gugatan yang melibatkan kepentingan sejumlah besar orang secara pefwakilan. Perbedaannya, dalam actio popularis yang berhak mengajukan gugatan adalah setiap orang atas dasar bahwa ia adalah anggota masyarakat, tanpa ada keharusan bahwa orang tersebut merupakan pihak yang mengalami kerugian secara langsung. Dalam class action tidak setiap orang berhak mengajukannya, melainkan hanya salah satu atau beberapa orang yang merupakan anggota dari sekelompok orang yang ikut mengalami kerugian secara langsung. Kepentingan yang dituntut dalam actio popularis adalah kepentingan umum yang dianggap kepentingan setiap anggota masyarakat juga, sedangkan dalam class action kepentingan yang dituntut adalah kepentingan yang sama dalam suatu permasalahan yang menimpa kelompok tersebut. Dalam sistem common law, prinsip actio popularis ini sama dengan citizen lawsuit seperti gugatan terhadap pelanggaran perlindungan lingkungan oleh warga negara, baik terhadap warga negara yang mengalami langsung terkena pencemarannya ataupun tidak, karena masalah perlindungan lingkungan merupakan kepentingan umum atau kepentingan masyarakat luas, maka setiap warga negara berhak menuntutnya. ${ }^{22}$

Di Belanda, dikenal groep acties yang mempunyai arti berbeda dengan pengertian gugatan perwakilan kelompok. Groep acties suatu pemberian hak gugat (standing) bagi suatu badan hukum untuk mewakili kepentingan orang banyak. ${ }^{23}$ Badan hukum tersebut tidak perlu merupakan bagian dari kelompok yang diwakilinya, namun cukup apabila didalam anggaran dasarnya mencantumkan perlindungan kepentingan masyarakat banyak yang diwakilinya. Gugatan perwakilan kelompok adalah masalah yang berkaitan dengan prosedur pengajuan perkara

${ }^{22}$ Mas Achmad Santosa, Konsep dan Penerapan gugatan Perwakilan (Class Action) (Jakarta: Indonesia Center for Environmental Law (ICEL), 1997), hlm 20.

${ }^{23}$ Paulus Efendi Lotulung, Penegakan Hukum Lingkungan Oleh Hakim Perdata (Bandung:: Citra Aditya Bakti, 1993), hlm 53. 
yang.melibatkan sekelompok orang yang mempunyai kepentingan serta permasalahan yang sama. Kepentingan yang dituntut dalam groep acties adalah kepentingan orang banyak dalam arti kepentingan umum dan tidak boleh menuntut ganti kerugian. Kepentingan yang dituntut dalam gugatan perwakilan kelompok adalah kepentingan yang sama dari sekelompok orang yang bersifat individual, yang umumnya berupa tuntutan ganti kerugian. Badan hukum yang mengajukan tuntutan dalam groep acties tidak harus mengalami kerugian secara nyata, atau tidak harus bertempat tinggal dalam satu daerah dengan masyarakat yang diwakili.

Di Indonesia pemberian hak gugat kepada badan hukum telah mengalami perkembangan pula yaitu dengan adanya pemberian hak gugat (standing) kepada organisasi non pemerintah (Non Government Organization). Pemberian hak gugat itu disertai dengan persyaratan organisasi non pemerintah tersebut berbentuk badan hukum dan di dalam Anggaran Dasarnya mencantumkan kegiatan yang sama dengan yang diperjuangkan di pengadilan. Beberapa kasus seperti kasus perlindungan konsumen dan pelestarian lingkungan adalah kasus publik, yaitu kasus yang menyangkut kepentingan masyarakat luas. Banyaknya kasus-kasus publik yang muncul mendorong organisasi-organisasi advokasi, seperti Sierra Club Defense Fund di Amerika Serikat, Polution Probe di Canada, Environmental Defenders Office di Australia, dan Yayasan Lembaga Bantuan Hukum Indonesia (YLBHI), Yayasan Lembaga Konsumen Indonesia (YLKI) serta Wahana Lingkungan Hidup Indonesia (Walhi) di Indonesia. Selain untuk mempejuangkan kepentingan masyarakat, organisasi-organisasi tersebut terbukti sangat efektif dalam mendorong pembaruan kebijakan, mengubah sikap juga perilaku birokrasi dan pengusaha melalui tekanan-tekanan yang dilakukan dalam bidang advokasi. Dalam rangka memperjuangkan misinya, organisasiorganisasi tersebut umumnya tidak mempunyai kepentingan hukum, dalam arti tidak mempunyai kepentingan pemilikan (propiertary) maupun kepentingan ekonomis.

Di sisi lain, untuk kepentingan masyarakat maupun lingkungan perlu diadakan suatu pengakuan hukum (legal recognition) yang memberikan peluang pada suatu organisasi untuk mengajukan gugatan. Peluang seperti ini sulit diperoleh di negara yang menganut sistem hukum civil law, karena doktrin hukum perdata yang dianut sistem hukum ini mensyaratkan adanya kepentingan hukum untuk dapat mengambil bagian di pengadilan sebagai penggugat. Dalam kasus yang menyangkut sumber daya alam, objek sumber daya alam (sungai, hutan, dan mineral atau tambang) yang pada umumnya dikuasai oleh negara, membawa konsekuensi bahwa sifat berkelanjutan sumber daya alam lebih banyak ditentukan dan bergantung pada konsekuensi, aktivisme, dan keberanian pemerintah sebagai aparatur negara.

Kenyataannya, seringkali pemerintah mengabaikan kewajibannya untuk melestarikan sumber daya alam. Pemerintah antara lain tidak menerapkan perizinan atau menjalankan fungsi pengawasan sebagaimana yang telah ditentukan oleh peraturan perundang-undangan. Keadaan semacam ini mengkibatkan kelompokkelompok masyarakat seperti LSM melakukan tindakan korektif, melalui jalur hukum. Agar tindakan korektif tersebut dapat dilakukan secara efektif, diperlukan penyediaan akses LSM ke pengadilan melalui pengembangan standing. 
Hak standing tidak secara otomatis menjamin keberhasilan litigasi kasus-kasus publik, karena pada dasarnya standing hanyalah merupakan "tiket masuk" ke dalam arena advokasi hukum (legal battle) yang sarat dengan berbagai kendala. Kendala itu antara lain berkaitan dengan kendala pembuktian, perangkat pemulihan, (remedial tools) yang tersedia, sampai pada kendala yang berkaitan dengan kesiapan majelis hakim dalam memberikan putusan terbaik. Oleh karena itu, pengembangan konsep standing sebagai salah satu hak prosedural dalam litigasi prosedural mutlak dilakukan. Hak-hak prosedural tersebut antara lain hak masyarakat atau pencari keadilan untuk mendapatkan akses pada saksi ahli, akses informasi, ketersediaan remedial tools yang memadai dalam gugatan perdata dan pengembangan sistem pertanggungjawaban strict liability. ${ }^{24}$

\section{Simpulan}

Terdapat perbedaan mendasar antara pengertian atau konsep gugatan perwakilan kelompok dengan konsep hak gugat (standing). Dalam class action tidak setiap orang berhak mengajukan gugatan, melainkan hanya salah-satu atau beberapa orang yang merupakan anggota dari sekelompok orang yang ikut mengalami kerugian secara langsung. Kepentingan yang dituntut dalam class action adalah kepentingan yang sama dalam suatu permasalahan yang menimpa kelompok tersebut.
Hak standing hanyalah merupakan "tiket masuk" ke dalam arena advokasi hukum (legal battle) yang sarat dengan berbagai kendala, antara lain berkaitan dengan pembuktian, perangkat pemulihan, (remedial tools) yang tersedia, sampai pada kendala yang berkaitan dengan kesiapan majelis hakim dalam memberikan putusan terbaik. Oleh karena itu, pengembangan konsep standing sebagai salah satu hak prosedural dalam litigasi prosedural mutlak dilakukan.

\section{Daftar Pustaka}

Black, Henry Campbell, Black's Law Dictionary (St. Paul, Minn: West Publishing Co., 1979).

Black's Law Dictionary, Sixth Edition, (ST. Paul, Minn: West Publishing Co. 1990).

Harron, Thomas J., Business Law (Boston: Allyn and Bacon, 1981).

Kupchale, Charles E. \& Margareth C. Hyland, Environmental Science (Massachusetts: Allyn \& Bacon, 1986)

Kane, Mary Kay, Civil Procedure, Third Edition (Minnesota: West Publishing Co., St. Paul, , 1991).

Lotulung, Paulus Efendi, Penegakan Hukum Lingkungan oleh Hakim Perdata (Bandung: Citra Aditya Bakti, 1993). , "Keynote Speech", Lokakarya Acara

${ }^{24}$ Strict Liabilityadalah suatu doktrin pertanggungjawaban perdata dibidang lingkungan hidup diamana tanggung jawab muncul seketika dan tidak harus berdasarkan pada kesalahan (liability without fault). Kajian mendalam tentang: Strict Liability baca: Mas Achmad Sentosa, "Penerapan Asas Tanggung Jawab Mutlak (Strict Liability) Dibidang Lingkungan Hidup." Jurnal ICEL ke Il, 1997, hlm.3 
Gugatan Perwakilan Kelompok (Class Action), (Forum Kajian Hukum Fakultas Hukum Universitas Pakuan - Lembaga Penelitian dan Pertimbangan Hukum Administrasi Negara, Bogor, 27 Juli 2002).

Penegakan Hukum Lingkungan Oleh Hakim Perdata (Bandung:: Citra Aditya Bakti, 1993).

Mertokusumo, Sudikno, Hukum Acara Perdata Indonesia, ed. Kelima, (Yogyakarta: Liberty. 1996).

Metzger, Michael B., et al, Business Law and
The Regulatory of Environment (Illinois: Inwin, 1986).

Nugroho, Susanti Adi, Praktek Gugatan Perwakilan Kelompok (Class Action) (Jakarta: Mahkamah Agung $\mathrm{Rl}, 2002$ ).

Santoso, Mas Achmad, et. al., Pedoman Penggunaan Gugatan Perwakilan (Jakarta: ICEL - PIAC - YLBHI, 1999). Konsep dan Penerapan Gugatan Perwakilan (Class Action) (Jakarta: ICEL, 1997). Konsep dan Penerapan gugatan Perwakilan (Class Action) (Jakarta: In- 